\title{
Mathematical Modelling in Agricultural Systems in Indonesia: A Case Study of Modelling in Predicting Production and Consumption Corn to Reach Corn Self-Sufficiency
}

\author{
Romli Ardie, Mukhtar, Cecep Anwar Hadi Firdos Santosa*, Sholih, Nana Hendracipta \\ Faculty of Education and Teaching Sciences \\ University of Sultan Ageng Tirtayasa \\ *email: cecepanwar@untirta.ac.id
}

\begin{abstract}
The study forecasting has been undertaken to fit different trend equations like time series models for corn and also made the future forecasts. The study was carried out in Indonesia using time series data from 1986 to 2017. Forecasting time series is a need in the agriculture sector or other fields. We present here the software $R$ as an important tool for forecasting and especially for studying the time series models. We review the past 29 years of research into time series forecasting. Forecasting is used to analysis the past and current behaviour to forecasts the future corn production and consumption which intern provide an aid to decision-making and in planning for the future effectively and efficiently. Autoregressive integrated moving average (ARIMA) model is the most widely used model for forecasting time series. In achieving corn self-sufficiency, there are many obstacles and challenges faced, including the decline in the rate of increase in agricultural land production, the conversion of agricultural land into non-agricultural land, sick or unproductive land, efforts to expand the area difficult and the increasing population. Agriculture is the backbone of the Indonesian economy. Corn is a very important need after rice for the food needs of the Indonesian people. This study generally aims to analyze the production and consumption of corn in Indonesia. Specifically aims to project corn production and consumption in Indonesia for the next five years (20182022), as well as its implications for corn self-sufficiency in Indonesia. The data used in this study is in the form of time series data for 31 years $(1986$ - 2017) and analyzed in forecasting Holt-Winters' methods and data processing using Microsoft Office Excel and R Software. The results of the study obtained results of the projection of corn production and consumption in Indonesia in 2018-2022 shows that Indonesia has a surplus of corn until 2022 so the government must be able to maintain it.
\end{abstract}

Keywords: time series, forecasting, food security, modelling real data, corn

\section{INTRODUCTION}

Food security is the basis for national stability and sustainable growth, especially for Indonesia, food demand continues to increase because there are too many people with little land and rapid economic growth. The problem of food security is an important topic because food is the most essential need that determines the quality of human resources and socio-political stability as a prerequisite for carrying out development (Bender, 2014).

Food security is becoming more important because food is not only a basic need but also a basic right for every human being that must be fulfilled. Because food is a basic right, the state has an obligation to ensure that every citizen has the right to food (Riches, 2016). At present the world is experiencing a food crisis which is marked by rising prices for the food sector, especially world food prices. Corn prices have surged with demand for commodities also increasing. Food import demand from various countries continues to increase.

Food security has received a lot of attention in recent years, both from academics and non-academics (Béné, Headey, Haddad, \& von Grebmer, 2016; Coleman-jensen \& Singh, 2014). This increased attention is particularly apparent after the 2007-2008 and 2010 world food price crises and the 2008 World Development Report, which calls for greater investment in agriculture in developing countries. These events make it clear that, despite decades of efforts to combat hunger and malnutrition, food insecurity is still a significant problem. In addition, it is increasingly clear that food security is strongly related to other issues, such as changes in the global environment and energy markets, and that the policy environment is undergoing transformation and globalization (Atkins \& Bowler, 2016; Buller, Henry, 2017; Groenewald, 2016; Hawkes \& Popkin, 2015; Isakson, 2014). For reasons of food security has become a concept that finds broad resonance among academic institutions and in policy considerations (Bruner \& Hahn, 2015; Candel, 2014; Nestle, 2010; Winter, 2004). 
In Indonesia, near about $45 \%$ of the population depends upon agriculture, directly or indirectly. So, Agriculture is the main contributor to development of economies in developing countries like Indonesia, accounting for around $45 \%$ of Indonesia's GDP.

Corn commodity is currently a strategic national commodity. The dominant corn is used as feed ingredients for livestock. High and low prices of animal feed, will greatly affect the price of livestock prices such as meat and eggs. The increase in corn prices will have an impact on the increase in the price of animal feed, and will result in an increase in the prices of eggs and meat.

In the period of 2011 - 2015 the total household consumption ranged from 350 to 460 thousand tons, while the use of corn for food also ranged in numbers that approached the range of use at the household level, but after 2009 an increase in the amount of corn to feed more than 1 million tons more. This is different from the total use of corn for non-food / industrial processes, which in 2011 - 2015 tended to increase slowly from 3.67 million tons in 2011 to 3.88 million tons in 2014. The use of high corn for processing was not food / industry occurs because the demand for corn for animal feed increases, along with the increase in livestock population due to the increasing demand for poultry meat.

The growth rate of corn consumption for industry is higher than household needs, in the period 2011-2014 the average growth in total household consumption increased $-1.02 \%$ per year, while the total consumption of corn for industry on average increased by 3,33\% per year. This shows the use of dry corn is more widely used in the animal feed industry than for household consumption.

Corn production in 2016 was 23.19 million tons, an increase of $18.23 \%$ from the previous year. This increase is the highest increase in the last 8 years. The increase in corn production in 2016 was more due to an increase in harvested area, while productivity increased by $1.07 \mathrm{kw} / \mathrm{ha}(2.07 \%)$. Conversely, there was a significant increase in harvested area of 600 thousand hectares $(15.85 \%)$.

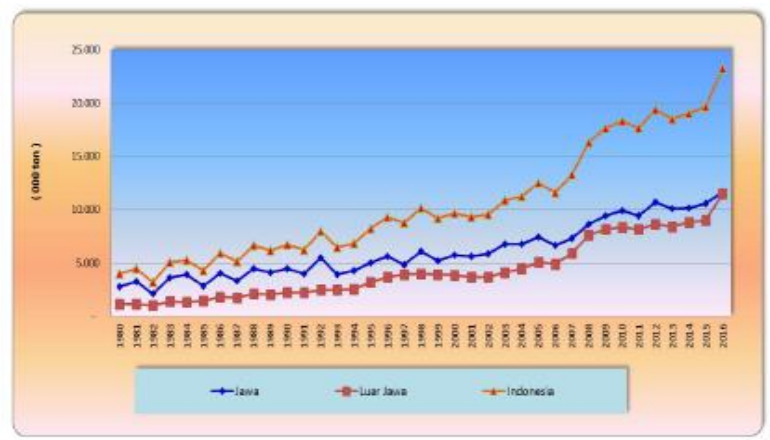

Figure 1. Development of Corn Production in Indonesia, 1980-2016
Components for large use of corn include direct consumption, feed consumption, other non-feed industries, seed use and other uses. Corn consumed directly is calculated based on the SUSENAS consumption rate in 2013 of $1.65 \mathrm{~kg} /$ capita / year. If it is assumed that corn is consumed by the entire population in 2013 (248.82 million people) then this direct consumption is 410.55 thousand tons.

The amount of corn consumption for food will continue to increase along with the increase in population, and in line with the increase in income. In addition, an increase in livestock populations that use corn as feed will encourage the animal feed industry and other industries that use corn as part of their raw materials. This means increasing demand for corn from year to year.

consisting of elements, relations, operations, and rules governing interaction) expressed using an external notation system, and which is used to construct, describe, or explain the behavior of other systems - perhaps so that other systems can be manipulated or predicted intelligently. Mathematical models focus on structural characteristics (rather than, for example, physical or musical characteristics) of the relevant system (Ignatov \& Mosin, 2013).

Mathematical modelling plays an integral role in the development of agricultural systems and they represent the key functions of a system (El-Zohri, Shafey, Abdel-Salam, \& Ahmed, 2011; Ignatov \& Mosin, 2013; Kaylen, Loehman, \& Preckel, 1989; Morrison, Kingwell, Pannell, \& Ewing, 1986; Philips \& O’Callaghan, 1974; Shahir, Sulthan (Tamil Nadu Agricultural University, Rangaraju, Visvanathan (Tamil Nadu Agricultural University, Eyarkai, Nambi Vijayaram (Tamil Nadu Agricultural University, \& Veerapandian, Chandrasekar (Tamil Nadu Agricultural University, 2015; Tedeschi, 2006). Mathematical models are the basic tools for developing mechanistic plant simulation models. This allows complex biological systems in agriculture to be analysed and understood (France and Thornley 1984). In this paper, the application of mathematical models in the development of corn growth will be highlighted. Various benefits of this model in research to formulate sustainable agriculture will also be shown (Tedeschi, 2006).

With the detail from previous study, various ways of prediction are available such as, Mathematical modelling, Recurrent network, Time Series Analysis, Machine Learning method such as ANNs (Time-delay network), Self-organizing maps etc. Among them, Time Series Analysis is more reliable when data represents a broad time period (Forecasting, 2010; Series \& Methods, 2014; Ya, Series, \& Lp, 2007).The main aim of time series modelling is to carefully collect and rigorously study the past observations of a time series to develop an appropriate model which describes the inherent structure of the series.

This model is then used to generate future values for the series, i.e. to make forecasts. Time series forecasting thus can 
be termed as the act of predicting the future by understanding the past.

Keeping the above requirement in view, the present study was carried out to (i) the development of corn production and consumption in Indonesia (ii) factors influence the production and consumption of corn in Indonesia, (iii) forecast and validate the rice area, production, and productivity using ARIMA models, and (iv) factors that influence corn production and consumption in Indonesia, how much is corn production and consumption in the next five years (20182022), and how does that imply corn self-sufficiency in Indonesia.

\section{Data}

\section{MATERIAL AND METHODS}

For this study, consumption and production data which includes variables of land area, production, household consumption and consumption for industry were obtained for the period 1986 to 2016. Obtained through the Indonesian statistical center and the Indonesian Ministry of Agriculture.

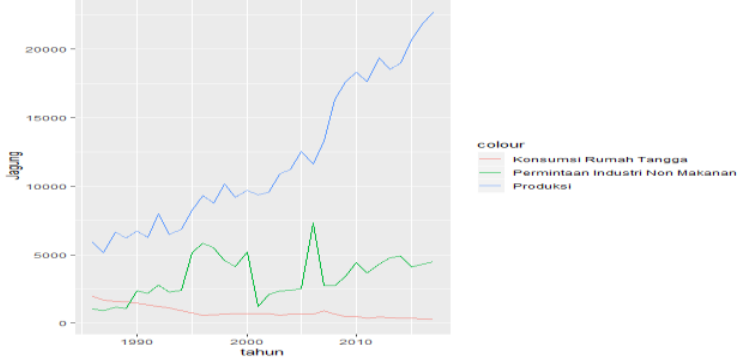

Figure 2. The number of corn product, consumption, and industry per year from 1986 to 2017

In the picture above it can be seen in general that there is an increase in production from year to year. For industry needs fluctuate from year to year. While household consumption from year to year has decreased.

\section{Time Series}

Time series (TS) data refers to observation on variable that occur in a time sequence. Mostly these observations are collected at equally spaced, discrete time intervals. A basic assumption in any time series analysis/modelling is that some aspects of the past pattern is based usually on past values of the main variable but not on explanatory variables which able to know about 'what' will happen rather than 'why' it happens. So if time series models are put to use for forecasting purposes, than they are especially applicable in the 'short term'.

The number of observations was based on the central limit theorem in statistics. The central limit theorem state that as the number of discrete events increases, the function begins to resemble a normal distribution. Annual data from year 1986 to 2017 for a period of 31 years were used in the study. Time series data of the selected indicators on the three dimensions namely production, harvest area, household consumption, and industry demand for non-food.

A time-series model is one which postulates a relationship amongst a number of temporal sequences or time series. An example is provided by the simple regression model

$$
y(t)=x(t)+\varepsilon(t)
$$

Where $y(t)=\left\{y_{t} ; t=0, \pm 1, \pm 2, \ldots\right\}$ is a sequence, indexed by the time subscript $t$, which is a combination of an observable signal sequence $x(t)=\left\{x_{t}\right\}$ and an unobservable white-noise sequence $(t)=\left\{\varepsilon_{t}\right\}$ of independently and identically distributed random variables.

The model may be represented by the equation

$\sum_{i=0}^{p} \alpha_{i} y(t-i)=\sum_{i=0}^{k} \beta_{i} x(t-i)+\sum_{i=0}^{q} \mu_{i} \varepsilon(t-i)_{i}$

The foregoing models are termed regression models by virtue of the inclusion of the observable explanatory sequence $x(t)$. When $x(t)$ is deleted, we obtain a simpler unconditional linear stochastic model:

$\sum_{i=0}^{p} \alpha_{i} y(t-i)=\sum_{i=0}^{q} \mu_{i} \varepsilon(t-i)$

A time-series model can often assume a variety of forms. Consider a simple dynamic regression model of the form

$y(t)=\varphi y(t-1)+x(t) \beta+\varepsilon(t)$,

where there is a single lagged dependent variable. By repeated substitution, we obtain

$y(t)=\varphi y(t-1)+x(t) \beta+\varepsilon(t)$

$y(t)=\varphi^{2} y(t-1)+\beta\{x(t)+\varphi x(t-1)\}+\varepsilon(t)+\varphi \varepsilon(t-1)$

$$
\begin{aligned}
& \quad \ddot{y}(t)=\varphi^{n} y(t-n)+\beta\left\{x(t)+\varphi x(t-1)+\cdots+\varphi^{n-1} x(t-n+1)\right\}+\varepsilon(t)+\varphi \varepsilon(t-1)+\cdots \\
& \quad+\varphi^{n-1} \varepsilon(t-n+1) \\
& \quad \text { If }|\varphi|<1 \text {, then } \lim (n \rightarrow \infty) \varphi^{n}=0 ; \text { and it }
\end{aligned}
$$

follows that, if $x(t)$ and $\varepsilon(t)$ are bounded sequences, then, as the number of repeated substitutions increases indefinitely, the equation will tend to the limiting form of

$$
y(t)=\beta \sum_{i=0}^{\infty} \varphi^{i} x(t-i)+\sum_{i=0}^{\infty} \varphi^{i} \varepsilon(t-i) \text {. }
$$

\section{Point forecasts for all methods}

We denote the observed time series by $y_{1}, y_{2}, \ldots, y_{n}$. Hyndman dan Khandakar (2008) declare a forecast of based 
on $y_{t+h}$ all of the data up to time $\mathrm{t}$ is denoted by $\widehat{y_{t+h \mid t}}$ To illustrate the method, we give the point forecasts and updating equations for method (A,A), the Holt-Winters' additive method:

Level:

$$
l_{t}=\alpha\left(y_{t}-s_{t-m}\right)+(1-\alpha)\left(l_{t-1}+b_{t-1}\right)
$$

Growth: $b_{t}=\beta^{*}\left(l_{t}-l_{t-1}\right)+\left(1-\beta^{*}\right) b_{t-1}$

Seasonal:

$$
s_{t}=\gamma\left(y_{t}-l_{t-1}-b_{t-1}\right)+(1-\gamma) s_{t-m}
$$

Forecast: $\quad y_{t+h \mid t}=l_{t}+b_{t} h+s_{t-m+h_{m}^{+}}$

(1d)

\section{Forecasts accuracy measuring tools}

After model selection, a next important step is to measure the accuracy to verify the reliability of forecasted value based selected model. Various tools are available in literature which includes Root mean square error (RMSE), mean absolute error (MAE), mean absolute percentage error (MAPE), mean error (ME) and mean percentage error (MPE). Further computation and literature of these accuracy measuring tools are given in table 1 .

Table 1. Measuring Accuracy of Forecasting Methods

\begin{tabular}{|l|l|l|}
\hline $\begin{array}{c}\text { Accuracy } \\
\text { measuring } \\
\text { tool }\end{array}$ & \multicolumn{1}{|c|}{ Formulation } & \multicolumn{1}{|c|}{ Reference } \\
\hline MAE & $M A E=\frac{\sum_{t=1}^{n}\left|\varepsilon_{t}\right|}{n}$ & $\begin{array}{l}\text { Makridakis } \text { et } \\
\text { al., 2003 }\end{array}$ \\
\hline $\mathrm{ME}$ & $M E=\frac{\sum_{t=1}^{n} \varepsilon_{t}}{n}$ & $\begin{array}{l}\text { Makridakis } \text { et } \\
\text { al., 2003 }\end{array}$ \\
\hline MSE & $M S E=\frac{1}{n} \sum_{t=1}^{n} \varepsilon_{t}^{2}$ & $\begin{array}{l}\text { Makridakis } \text { et } \\
\text { al., 2003 }\end{array}$ \\
\hline MPE & $M P E=\frac{1}{n} \sum_{t=1}^{n} P E_{t}$ & $\begin{array}{l}\text { Makridakis } \text { et } \\
\text { al., 2003 }\end{array}$ \\
\hline MAPE & $M A P E=\frac{1}{n} \sum_{t=1}^{n}\left|P E_{t}\right|$ & $\begin{array}{l}\text { Makridakis } \text { et } \\
\text { al, 2003 }\end{array}$ \\
\hline
\end{tabular}

$$
P E_{t}=\left(\frac{Y_{t}-F_{t}}{Y_{t}}\right) x 100 \text { Where and } F t \text { is the forecasted }
$$

value for time $t$.

In the present study, Auto Regressive Integrated Moving Average (ARIMA) and Exponential smoothing methods like Holt-Winter's Exponential smoothing that methods have been fitted to the data on area, production and consumption of the major corn in Indonesia by considering 31 years data from 1986 to 2017 . The results are presented as follows.

\section{Forecasting Product}

The following is a picture showing corn production from 1986 to 2017.

Corn is cultivated in nearly about 32 provinces having wider diversity of soil, climate, biodiversity and management practices that contributes $20 \%$. In the global corn production in Indonesia.

In Indonesia, corn is the second most important cereal crop after rice with an area of 4107.517 thousand hectares and production of 22673.495 thousand tones.

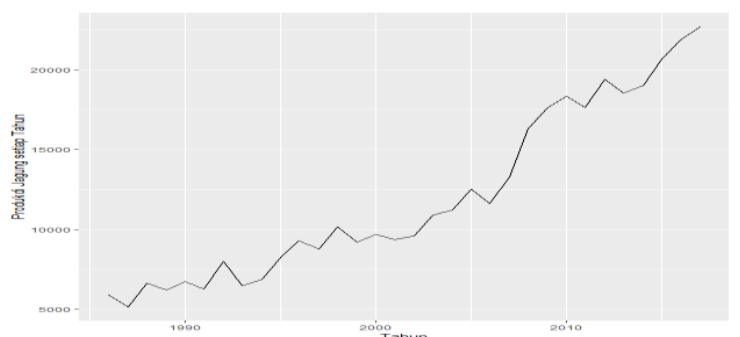

Figure 3. Corn Production

In the picture above it can be concluded that there is an increase from year to year. Then researchers will also test time series to predict the next five years. With forecasting functions with Holt Winter's method.

To build the model we need to arrange the data with frequency $m=1$. Data as follows:

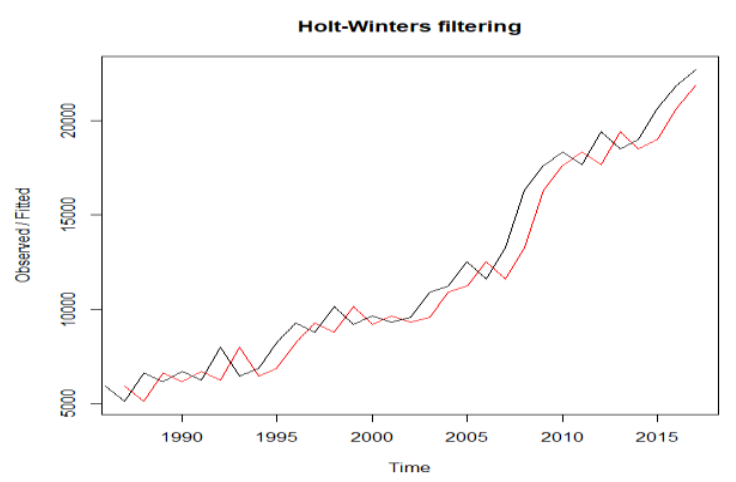

Figure 4. Holt-Winters filtering Method for Product

In the next step, a structure of the time series was analysed for the seasonality factor. The resulting correlogram was used to work out the relationship between individual values of the time series (Figure 4). Next steps were aimed at identifying an optimal model of exponential smoothing. Thus, a model with parameters for which the theoretical values would be as similar as possible to the observed ones. 


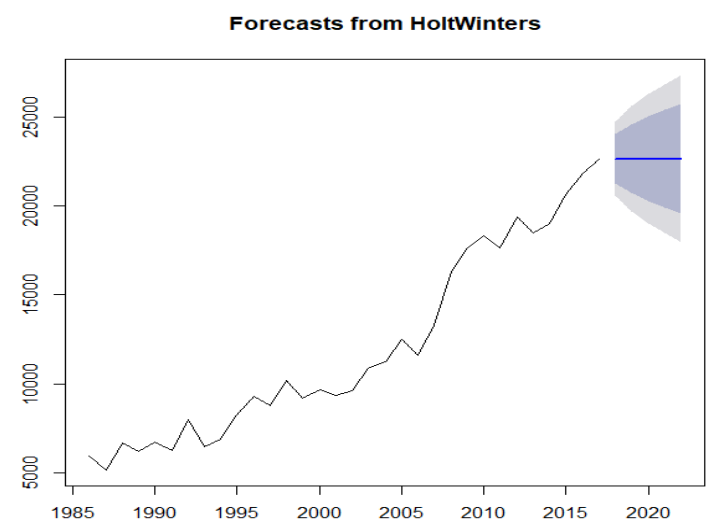

Figure 5. Forecasts from HoltWinters Product

Figure 5 shows the results of exponential smoothing for in Production and Consumption corn data and an annual forecast for 2018-2022. The fit of the assumed model to actual data was verified using mean error, mean absolute error, summed square of residuals, mean percentage error and mean absolute percentage error.

HoltWinters(jagung_idb1series, beta=FALSE, gamma=FALSE, I.start=5920) Holt-Winters exponential smoothing without trend and without seasonal component.

Call:

HoltWinters $(x=$ jagung_idb1series, beta $=$ FALSE, gamma $=$ FALSE, I.start $=$ 5920)

Smoothing parameters:

alpha: 0.9999192

beta : FALSE

gamma: FALSE

Coefficients:

$$
[, 1]
$$

a 22673.43

Error measures:

ME RMSE MAE MPE MAPE MASE

ACF1

Training set 490.80981174 .087992 .80923 .6478729 .6864810 .9867477 0.2413127

Forecasts:

Point Forecast Lo 80 Hi 80 Lo 95 Hi 95

$2015 \quad 18985.4817593 .5220377 .4316856 .6721114 .29$

$2016 \quad 18985.4817064 .8520906 .1116048 .1221922 .83$

$2017 \quad 18985.4816653 .0721317 .8915418 .3722552 .59$

$2018 \quad 18985.4816303 .8021667 .1614884 .2023086 .76$

$2019 \quad 18985.4815995 .0421975 .9214412 .0023558 .96$

$2020 \quad 18985.4815715 .3122255 .6513984 .1923986 .77$

$2021 \quad 18985.4815457 .6922513 .2713590 .1924380 .77$

$2022 \quad 18985.4815217 .6422753 .3113223 .0724747 .89$
Table 2. Projection of Corn Agricultural Products

\begin{tabular}{|c|c|r|}
\hline Year & Products & Growth $(\%)$ \\
\hline $201 *^{*}$ & 23086.76 & 1.790052 \\
\hline $201 *^{*}$ & 23558.96 & 2.004333 \\
\hline $2020^{*}$ & 23986.77 & 1.783525 \\
\hline $2021^{*}$ & 24380.77 & 1.616028 \\
\hline $2022^{*}$ & 24747.89 & 1.48344 \\
\hline \multicolumn{3}{|c}{ *prediction } \\
\hline
\end{tabular}

Despite many outliers and fluctuations in Production and Consumption corn data, good values of model fit were achieved. Mean error was small, and mean percentage error of $3.64 \%$ was low enough to indicate usefulness of this model in predicting actual values of the series. The model quality was significantly improved by low mean absolute percentage error, which means an average forecast differs from actual values by $\pm 9.68 \%$.

In our data the model is: Holt-Winteres exponential smoothing with trend and additive seasonal component and the smoothing parameters are: alpha $(\alpha)$ : 0.9999192 ; beta $(\delta): 0$; gamma (g): 0 .

Optimisation allowed for estimating the model parameters with the following values: $\alpha=0.522 ; \delta=0.000$ and $\mathrm{g}=0.000$. Here, the value of $\alpha$ meant that half of the previous observations were ignored. $\delta$ equal to zero indicated high stability of the seasonality factor. Finally, g equal to zero indicated the trend component constant for all values of the time series and their forecasts.

The final stage was a verification of the forecast for the generated model of 5-year prediction against actual values of flow intensity for 2018-2022.

\section{Forecasting area of corn farming}

The following is a picture showing area of Corn Farming from 1986 to 2017.

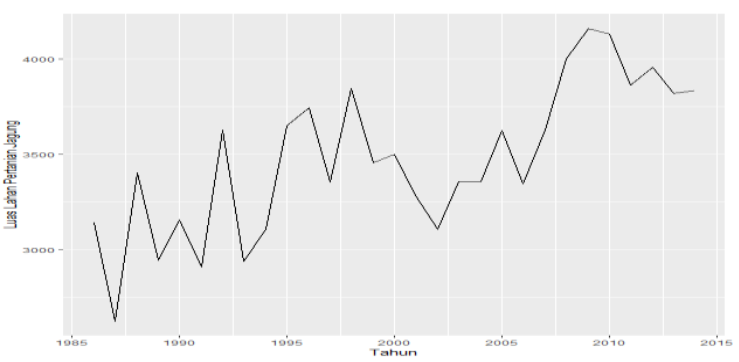

Figure 6. Area of Corn in Indonesia 


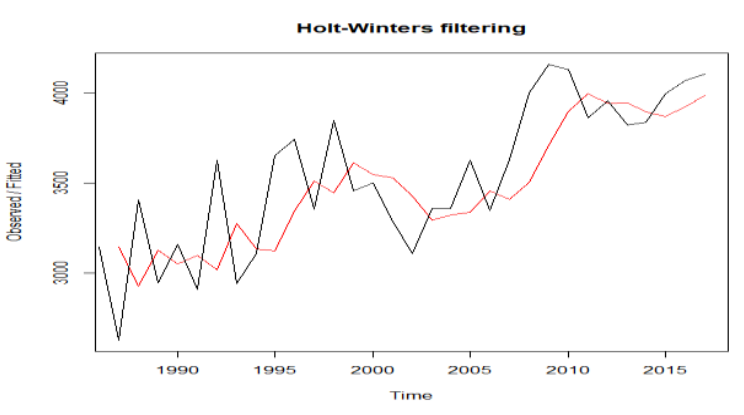

Figure 7. Holt-Winters filtering Method for Area

From the Figure 6, it was observed that the average area under corn during the study period (1986-2017) was 3533.908 thousand hectares in Indonesia. It was also observed that the area of corn crop has increased enormously from 1986 to 2017.

The results obtained for area of corn by fitting time series models were presented in Figure 8. In the next step, a structure of the time series was analysed for the seasonality factor. To this end, the resulting correlogram was used to work out the relationship between individual values of the time series (Figure 8).

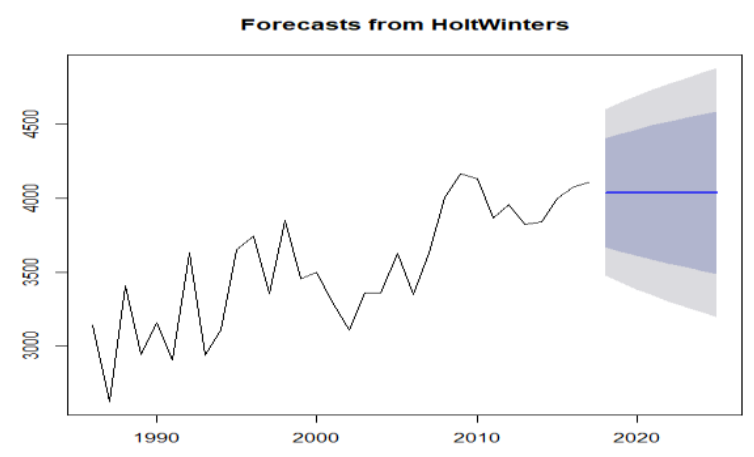

Figure 8. Forecasts from HoltWinters Area

Figure 8 shows the results of exponential smoothing for in Production and Consumption corn data and an annual forecast for 2018-2022. The fit of the assumed model to actual data was verified using mean error, mean absolute error, summed square of residuals, mean percentage error and mean absolute percentage error

jagung_idb2seriesforecasts\$SSE

[1] 2619588

Forecast method: HoltWinters

Model Information:

Holt-Winters exponential smoothing without trend and without seasonal component.

Call:

HoltWinters $(x=$ jagung_idb2series, beta $=$ FALSE, gamma $=$ FALSE $)$

Smoothing parameters:

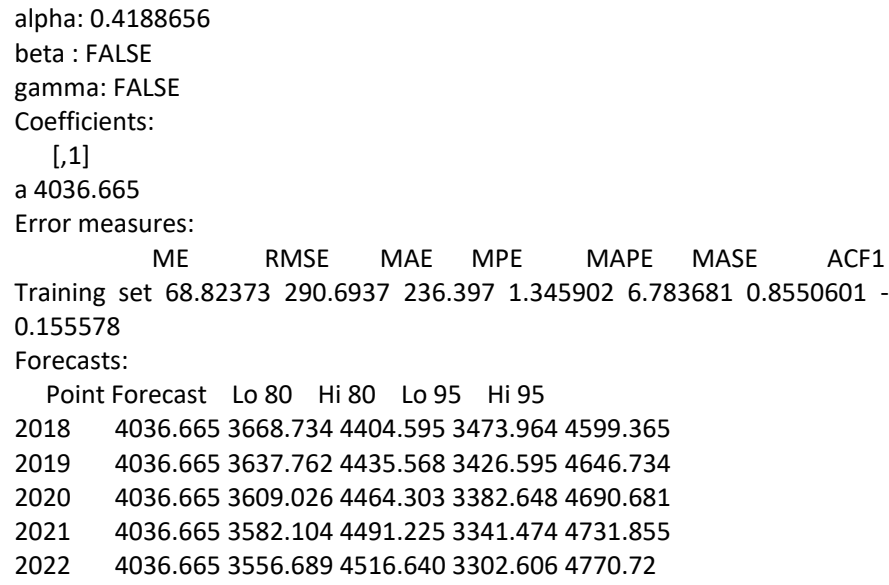

In area corn data, good values of model fit were achieved. Mean error was small, and mean percentage error of 1.345902 $\%$ was low enough to indicate usefulness of this model in predicting actual values of the series. The model quality was significantly improved by low mean absolute percentage error, which means an average forecast differs from actual values by $\pm 6.783681 \%$

Table 3. Projection of Corn Area

\begin{tabular}{|c|c|r|}
\hline Year & Land area & \multicolumn{1}{|c|}{ Growth } \\
\hline $2018^{*}$ & 4599.365 & 10.69382 \\
\hline $201 *^{*}$ & 4646.734 & 1.019404 \\
\hline $2020^{*}$ & 4690.681 & 0.9369 \\
\hline $2021^{*}$ & 4731.855 & 0.870145 \\
\hline $2022^{*}$ & 4770.724 & 0.81474 \\
\hline \multicolumn{3}{|c}{ * predicting }
\end{tabular}

In our data the model is: Holt-Winter's exponential smoothing with trend and additive seasonal component and the smoothing parameters are: alpha $(\alpha): 0.4188656$; beta $(\delta): 0$; gamma (g): 0 .

The final stage was a verification of the forecast for the generated model of 5-year prediction against actual values of flow intensity for 2018-2022.

\section{Forecasting Consumption}

The following is a picture showing Consumption of Corn from 1986 to 2017 


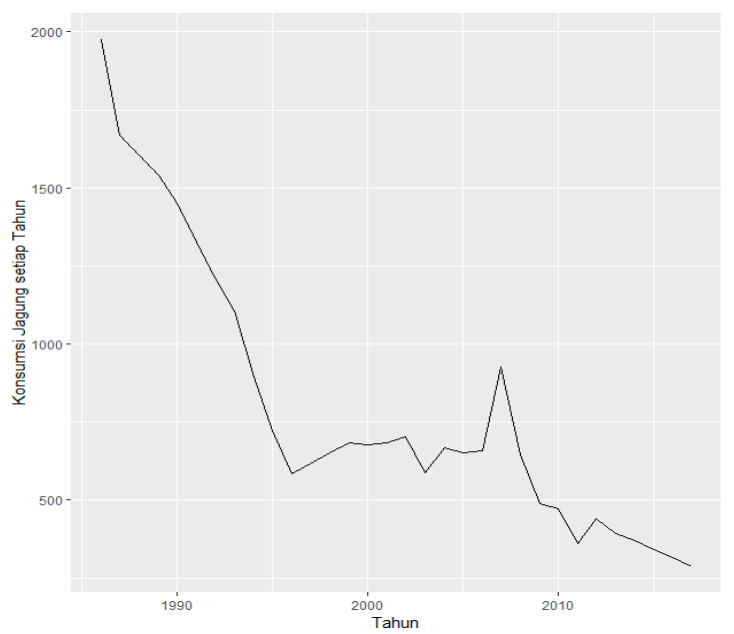

Figure 9. Consumption of Corn in Indonesia

From the Figure 9. It was observed that the average consumption of corn during the study period (1986-2017) was 802.9143438 ton $\mathrm{Kg}$ in Indonesia. It was also observed that the consumption of corn has decreased enormously from 1986 to 2017.

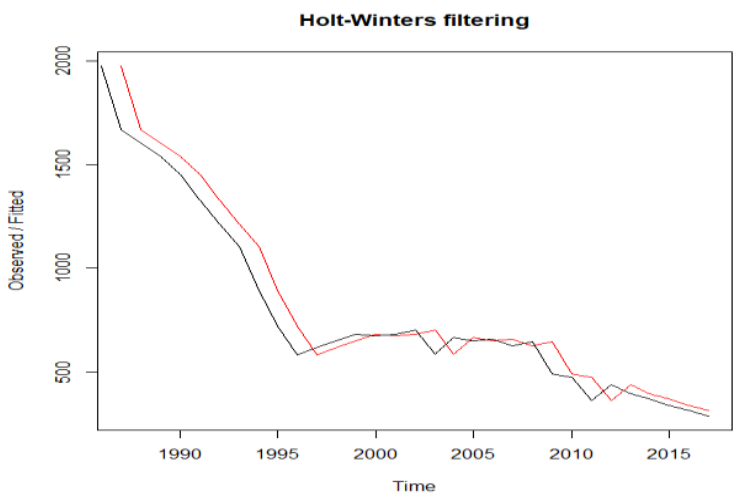

Figure 10. Holt-Winters filtering Method for Consumption

In the next step, a structure of the time series was analysed for the seasonality factor. To this end. The resulting correlogram was used to work out the relationship between individual values of the time series (Figure 11).

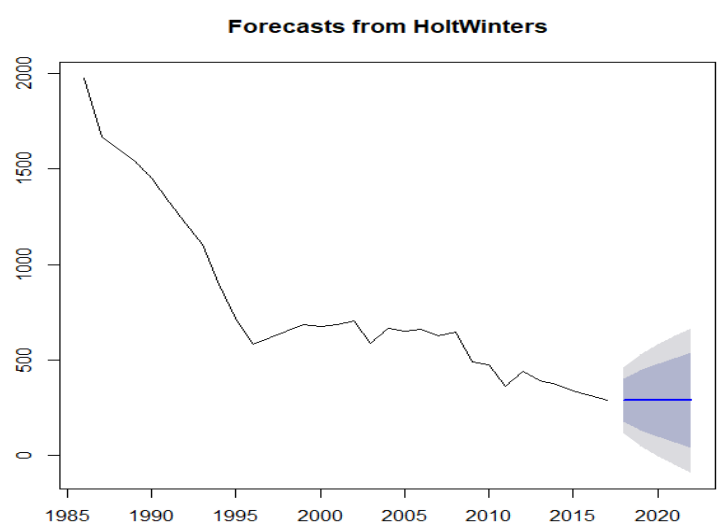

Figure 11. Forecasts from Holt Winters Consumption

Figure 11 shows the results of exponential smoothing for in Production and Consumption corn data and an annual forecast for 2018-2022. The fit of the assumed model to actual data was verified using mean error, mean absolute error, summed square of residuals, mean percentage error and mean absolute percentage error

Forecast method: HoltWinters

Model Information:

Holt-Winters exponential smoothing without trend and without seasonal component.

Call:

HoltWinters $(x=$ jagung_idb3series, beta $=$ FALSE, gamma $=$ FALSE $)$

Smoothing parameters:

alpha: 0.9999555

beta : FALSE

gamma: FALSE

Coefficients:

[,1]

a 288.0812

Error measures:

ME RMSE MAE MPE MAPE MASE ACF1

Training set $-54.4179 \quad 100.996 \quad 74.41239 \quad-7.029086 \quad 10.43631 \quad 1.000019$ 0.2218184

Forecasts:

Point Forecast Lo 80 Hi 80 Lo 95 Hi 95

$2018 \quad 288.0812177 .24238398 .9201118 .567837457 .5946$

$2019 \quad 288.0812131 .33491444 .827548 .358422527 .8040$

$2020 \quad 288.081296 .10840480 .0540-5.515872581 .6783$

$2021 \quad 288.081266 .41092509 .7515-50.934245627 .0967$

$2022 \quad 288.081240 .24685535 .9156-90.948750667 .1112$

Table 4. Projection of Consumption

\begin{tabular}{|c|c|c|}
\hline Year & Land area & Growth \\
\hline $2018^{*}$ & 457.5946 & 37.04471 \\
\hline $2019^{*}$ & 527.8040 & 13.30217 \\
\hline $2020^{*}$ & 581.6783 & 9.261872 \\
\hline $2021^{*}$ & 627.0967 & 7.242647 \\
\hline $2022^{*}$ & 667.1112 & 5.998175 \\
\hline \multicolumn{2}{|c}{ *prediction }
\end{tabular}


In Production and Consumption corn data, good values of model fit were achieved. Mean error was small, and mean percentage error of $7.029086 \%$ was low enough to indicate usefulness of this model in predicting actual values of the series. The model quality was significantly improved by low mean absolute percentage error, which means an average forecast differs from actual values by $\pm 10.43631 \%$.

In our data the model is: Holt-Winter's exponential smoothing with trend and additive seasonal component and the smoothing parameters are alpha $(\alpha): 0.4188656$; beta $(\delta): 0$; gamma $(\mathrm{g}): 0$.

The final stage was a verification of the forecast for the generated model of 5-year prediction against actual values of flow intensity for 2018-2022.

\section{Forecasting Industry}

The following is a picture showing Industry of Corn from 1986 to 2017

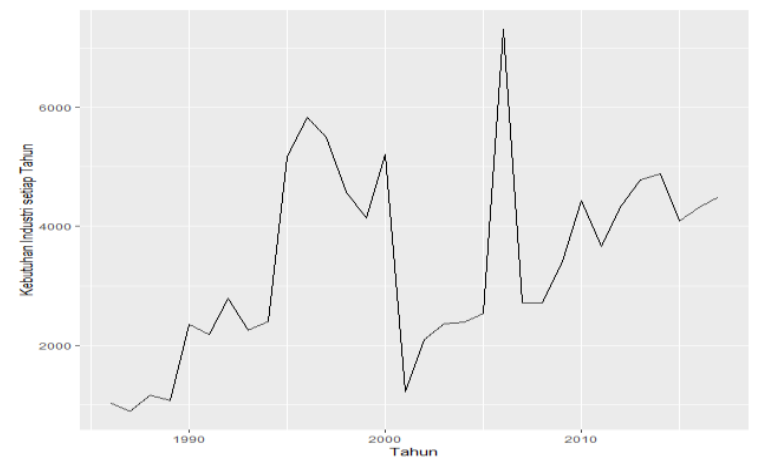

Figure 12. Industry of Corn in Indonesia

Figure 12, corn productivity in Indonesia from 1986 until 2017 it continued to experience fluctuations and tended to increase at three last year.

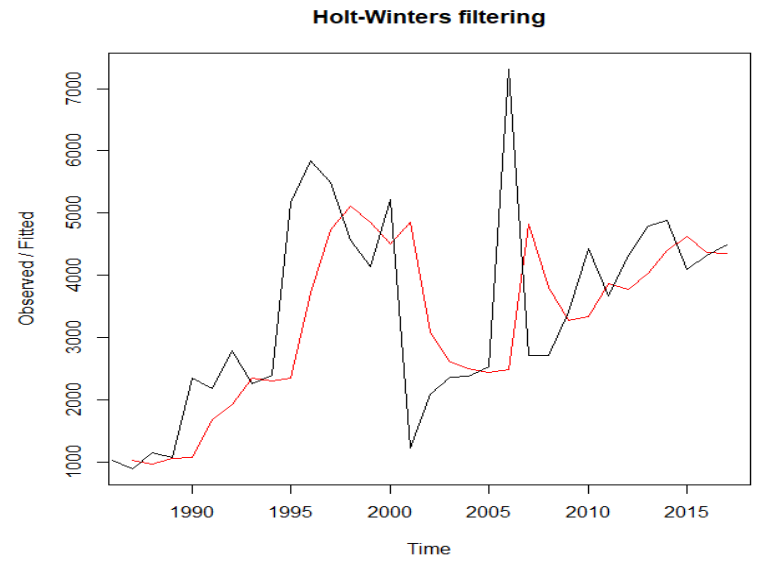

Figure 13. Holt-Winters filtering Method for Industry
In the next step, a structure of the time series was analysed for the seasonality factor. To this end. The resulting correlogram was used to work out the relationship between individual values of the time series (Figure 14).

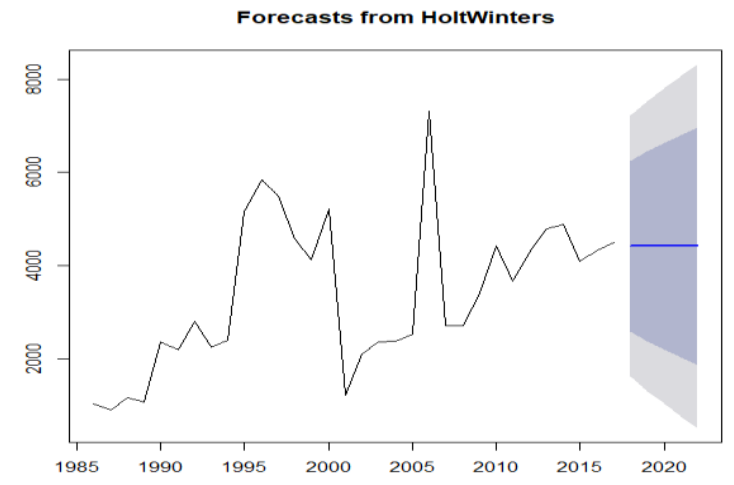

Figure 14. Forecasts from HoltWinters Industry

Figure 14 shows the results of exponential smoothing for in Industry corn data and an annual forecast for 2018-2022.

Forecast method: HoltWinters

Model Information:

Holt-Winters exponential smoothing without trend and without seasonal component.

Call:

HoltWinters $(x=$ jagung_idb4series, beta $=$ FALSE, gamma $=$ FALSE $)$

Smoothing parameters:

alpha: 0.4831363

beta : FALSE

gamma: FALSE

Coefficients:

[,1]

a 4416.378

Error measures:

ME RMSE MAE MPE MAPE MASE

ACF1

Training set $226.05631423 .249898 .6977-4.99690230 .072380 .9617164$ 0.01295486

Forecasts:

Point Forecast Lo 80 Hi 80 Lo $95 \quad \mathrm{Hi} 95$

$2018 \quad 4416.3782585 .7986246 .9591616 .74697216 .010$

$2019 \quad 4416.3782383 .3456449 .4121307 .12237525 .635$

$2020 \quad 4416.3782199 .3036633 .4541025 .65437807 .103$

20214416.3782029 .4096803 .348765 .82418066 .933

$2022 \quad 4416.3781870 .8296961 .928523 .29698309 .460$

Table 5. Projection of Industry

\begin{tabular}{|c|c|r|}
\hline Year & Industry & Growth \\
\hline $2018^{*}$ & 7216.010 & 37.78623 \\
\hline $2019^{*}$ & 7525.635 & 4.114271 \\
\hline $2020^{*}$ & 7807.103 & 3.605281 \\
\hline $2021 *$ & 8066.933 & 3.220927 \\
\hline $2022 *$ & 8309.460 & 2.918685 \\
\hline \multicolumn{3}{|c|}{ *prediction } \\
\hline
\end{tabular}


In our data the model is: Holt-Winter's exponential smoothing with trend and additive seasonal component and the smoothing parameters are: alpha $(\alpha): 0.4188656$; beta $(\delta): 0$; gamma $(\mathrm{g})$ : 0 .

The final stage was a verification of the forecast for the generated model of 5-year prediction against actual values of flow intensity for 2018-2022.

\section{DISCUSSIONS}

The results of the Indonesian corn consumption and productivity projection shows that all presumptive sign parameters are in line with forecasting in the time series.

The rate of growth of corn consumption was $10.62 \%$ higher than the growth rate of corn production of $1,74 \%$, but Indonesia reached the surplus state of corn. As shown in Table 6. The year 2018 to 2022 Indonesia still experiences a surplus of corn, but if there is a strong effort to maintain and even increase corn production that has been achieved now, Indonesia will arrive at a surplus state of corn in 2022.

Table 6. Projection of Consumption

\begin{tabular}{|c|r|r|r|r|r|}
\hline Year & Consumption & $\begin{array}{c}\text { consumption } \\
\text { growth }(\%)\end{array}$ & Productivity & $\begin{array}{c}\text { Productivity } \\
\text { Growth }(\%)\end{array}$ & $\begin{array}{c}\text { Surplus(+)/ } \\
\text { Defisit(-) }\end{array}$ \\
\hline $2018^{*}$ & 7673.605 & 37.74201 & 23086.76 & 1.790052 & 15413.16 \\
\hline $2019^{*}$ & 8053.439 & 4.71642 & 23558.96 & 2.004333 & 15505.52 \\
\hline $2022^{*}$ & 8388.781 & 3.997506 & 23986.77 & 1.783525 & 15597.99 \\
\hline $2021^{*}$ & 8694.03 & 3.511018 & 24380.77 & 1.616028 & 15686.74 \\
\hline $2022^{*}$ & 8976.571 & 3.147538 & 24747.89 & 1.48344 & 15771.32 \\
\hline Average & 8357.285 & 10.6229 & 23952.23 & 1.735476 & 15594.95 \\
\hline
\end{tabular}

The projection of corn production and consumption in Table 6 Indonesia will become a corn surplus country in 2022. Ligawati (2016) states that production can meet domestic corn consumption, this condition will lead Indonesia to become an independent country in fulfilling its food, especially corn, corn imports to cover domestic corn consumption can be reduced.

Food self-sufficiency can be achieved if food needs can be met by domestic production (Ewing-Chow \& Vilarasau Slade, 2012; Pinstrup-Andersen \& Pandya-Lorch, 1996; Syemin, 2010). When referring to this definition, it can be concluded that in the period 2018-2022 Indonesia can achieve corn selfsufficiency. Then Hessie (2009) stated that to achieve food self-sufficiency in this case, corn is certainly a lot of things that must be prioritized and carried out by the government in order to increase corn production. In increasing the growth of corn production, it can be done by optimizing the use of land resources, in the form of developing planting areas through intensification and intensification. This is in line with Kamaluddin (2017) stating that to achieve food selfsufficiency, the government must improve 1) Technology and education; 2) Rural cooperatives; 3) Infrastructure.

\section{CONCLUSION}

Corn production in Indonesia from 1986-2017 showed an increase with an average growth of $1.735476 \%$ per year and a total average production of 2.395223 million tons per year. This makes us able to corn self-sufficient in 2018-2022, so the government does not need to import corn. This will have a positive impact on corn farmers.

In connection with the above, it is necessary to continue the steps to handle the increase in agricultural productivity in order to realize corn self-sufficient in the context of national security with a systematic, integrated and comprehensive approach.

\section{REFERENCES}

ATKINS, P., \& BOWLER, I. (2016). FOOD IN SOCIETY: ECONOMY, CULTURE, GEOGRAPHY. ROUTLEDGE.

BENDER, D. (2014). AN INTRODUCTION TO NUTRITION AND METABOLISM. CRC PRESS.

Béné, C., HeAdey, D., Haddad, L., \& VON Grebmer, K. (2016). IS RESILIENCE A USEFUL CONCEPT IN THE CONTEXT OF FOOD SECURITY AND NUTRITION PROGRAMMES? SOME CONCEPTUAL AND PRACTICAL CONSIDERATIONS. FOOD SECURITY, 8(1), 123-138. HTTP://DOI.ORG/10.1007/S12571-015-0526-X

BRuner, M. S., \& HAHN, L. K. (2015). IRONY AND FoOD POLITICS. COMMUNICATION AND CRITICAL/ Cultural STUdies, 12(2), 214-217. HTTP://DOI.ORG/10.1080/14791420.2015.1014185

BUller, HENRY, AND K. H. (2017). AGRICULTURAL TRANSFORMATION, FOOD AND ENVIRONMENT: PERSPECTIVES ON EUROPEAN RURAL POLICY AND PLANNING-VOLUME 1. ROUTLEDGE.

CANDEL, J. J. L. (2014). FOOD SECURITY GOVERNANCE: A SYSTEMATIC LITERATURE REVIEW. FOOD SECURITY, 6(4), 585-601. HTTP://DOI.ORG/10.1007/S12571-0140364-2

Coleman-Jensen, A., \& Singh, A. (2014). Household Food SECURITY IN THE UNITED STATES IN 2013.

El-Zohri, E. H., ShafeY, H. M., ABDEl-SAlaM, M., \& AHMED, A. (2011). MATHEMATICAL MODELING OF AGRICULTURAL FIRES BENEATH HIGH VOLTAGE TRANSMISSION LINES. ENERGY, 36(1), 385-396. HTTP://DOI.ORG/10.1016/J.ENERGY.2010.10.027

EWING-ChOW, M., \& Vilarasau Slade, M. (2012). FoOD SECURITY: FROM SELF-SUFFICIENCY TO PRODUCTION DIVERSIFICATION AND REGIONAL COOPERATION - A CASE STUDY IN RICE SECURITY. SSRN.

Forecasting, T. S. (2010). TIME SERIES ForeCASTING. PREDICTIVE ANALYTICS AND DATA Mining. HTTP://DOI.ORG/10.1016/B978-0-12-8014608.00010-0

GroENEWALD, C. (2016). SOCIAL TRANSFORMATION BETWEEN GLOBALIZATION AND LOCALIZATION. SCRIPTURA, 72, 17-29.

Hawkes, C., \& Popkin, B. M. (2015). CAN THE SUSTAinable DEVELOPMENT GOALS REDUCE THE BURDEN OF NUTRITION-RELATED NON-COMMUNICABLE DISEASES 
WITHOUT TRULY ADDRESSING MAJOR FOOD SYSTEM REFORMS? BMC MEDICINE, 13(1), 143.

Hessie, R. (2009). ANALISIS PRODUKSI DAN KONSUMSI BERAS DALAM NEGERI SERTA IMPLIKASINYA TERHADAP SWASEMBADA BERAS DI INDONESIA. THESIS. INSTITUT PERTANIAN BOGOR. RETRIEVED FROM HTTP://REPOSITORY.IPB.AC.ID/BITSTREAM/HANDLE/12 3456789/14198/H09RHE.PDF

HYNDMAN, R. J., \& KHANDAKAR, Y. (2008). AUTOMATIC TIME SERIES FORECASTING : THE FORECAST PACKAGE FOR R AUTOMATIC TIME SERIES FORECASTING: THE FORECAST PACKAGE FOR R. JOURNAL OF STATISTICAL SOFTWARE, 27(3), 1-22. HTTP://DOI.ORG/10.18637/JSS.V027.I03

IGNATOV, I., \& MOSIN, O. (2013). STRUCTURAL MATHEMATICAL MODELS DESCRIBING WATER Clusters. MATHEMATICAL THEORY AND MODELING, 3(11), 2224-5804. RETRIEVED FROM WWW.IISTE.ORG

ISAKSON, S. R. (2014). FOOD AND FINANCE: THE FINANCIAL TRANSFORMATION OF AGRO FOOD SUPPLY CHAIN. JOURNAL OF PEASANT STUDIES, 41(5), 749-775.

KAMALUDDIN, A. (2017). EMPOWERMENT OF FARMERS AND Sustainable STRATEgIES TOWARDS THE SELFSUFFICIENCY OF RICE AND CORN IN INDONESIA. INTERNATIONAL JOURNAL OF CURRENT RESEARCH IN BiosCIENCE AND Plat Biology, 4(2), 45-53.

Kaylen, M. S., Loehman, E. T., \& Preckel, P. V. (1989). FARM-LEVEL ANALYSIS OF AGRICULTURAL INSURANCE: A MATHEMATICAL PROGRAMMING APPROACH. AGRICULTURAL SYSTEMS, 30(3), 235244. HTTP://DOI.ORG/10.1016/0308-521X(89)900899

LigAWATI, L. (2016). ANALISIS PRODUKSI DAN KONSUMSI JAGUNG DOMESTIK DALAM RANGKA PENCAPAIAN SWASEMBADA JAGUNG NASIONAL TAHUN 2017. INSTITUT PERTANIAN BOGOR. RETRIEVED FROM HTTPS://REPOSITORY.IPB.AC.ID/BITSTREAM/HANDLE/1 23456789/85887/H16LLI.PDF?SEQUENCE=1\&ISALLO $\mathrm{WED}=\mathrm{Y}$

Morrison, D. A., Kingwell, R. S., PANnell, D. J., \& EWING, M. A. (1986). A MATHEMATICAL PROGRAMMING MODEL OF A CROP-LIVESTOCK FARM SYSTEM. AGRICULTURAL SYSTEMS, 20(4), 243-268. HTTP://DOI.ORG/10.1016/0308-521X(86)90116-2

NESTLE, M. (2010). SAFE FOOD : THE POLITICS OF FOOD SAFETY. CALIFORNIA STUDIES IN FOOD AND CULTURE (VOL. 5). HTTP://DOI.ORG/10.1017/CBO9781107415324.004

Philips, P. R., \& O’CALlaghan, J. R. (1974). CEREAL HARVESTING - A MATHEMATICAL MODEL. JOURNAL OF AGRICULTURAL ENGINEERING RESEARCH, 19(4), 415-433. HTTP://DOI.ORG/10.1016/0021$\underline{8634(74) 90080-8}$
PinSTRUP-ANDERSEN, P., \& PANDYA-LORCH, R. (1996). FOOD FOR ALL IN 2020: CAN THE WORLD BE FED WITHOUT DAMAGING THE ENVIRONMENT? ENVIRONMENTAL CONSERVATION, 23(3), 226. HTTP://DOI.ORG/10.1017/S0376892900038844

RICHES, G. (2016). FIRST WORLD HUNGER: FOOD SECURITY AND WELFARE POLITICS. SPRINGER.

Series, T., \& Methods, A. (2014). Time Series Analysis Methods. Data ANALYSIS METHOdS IN PhySICAL OCEANOGRAPHY. HTTP://DOI.ORG/10.1016/B978-012-387782-6.00005-3

SHAHIR, SUlTHAN (TAMIL NADU AGRICULTURAL UNIVERSITY, C. (INDiA). D. OF F. AND A. P. E., RANGARAJU, VisVANATHAN (TAMIL NADU Agricultural University, C. (INDIA). D. OF F. AND A. P. E., EYARKAI, NAMBI VIJAYARAM (TAMIL NADU Agricultural UNIVERSITY, C. (INDiA). D. OF F. AND A. P. E., \& VEERAPANDIAN, ChANDRASEKAR (TAMIL NADU Agricultural University, C. (INDIA). D. OF F. AND A. P. E. (2015). MODELING THE MASS OF BANANA FRUIT BY GEOMETRICAL ATTRIBUTES. ПОљОПРИВРЕДНА ТЕХНИКА / Agricultural ENGINEERING, 40(2), 91-99. RETRIEVED FROM HTTP://JAGENG.AGRIF.BG.AC.RS/FILES/CASOPIS/PT_0 2-2015.PDF

SYEMIN, A. I. (2010). REGIONAL FOOD SECURITY: GENERATING FACTORS AND MECHANISMS FOR MAINTAINING IT. EKONOMIKA SEL'SKOKHOZYAISTVENNYKH I PERERABATYVAYUSHCHIKH PREDPRIYATII, (5), 8-13. RETRIEVED FROM HTTP://SEARCH.EBSCOHOST.COM/LOGIN.ASPX?DIREC $\mathrm{T}=\mathrm{TRUE} \& \mathrm{DB}=\mathrm{LAH} \& \mathrm{AN}=20103379776 \&$ SITE $=$ EHOST -LIVE\%5CNEMAIL: REKTOR@USACA.RU

TEDESCHI, L. O. (2006). ASSESSMENT OF THE ADEQUACY OF MATHEMATICAL MODELS. AGRICULTURAL SYSTEMS. HTTP://DOI.ORG/10.1016/J.AGSY.2005.11.004

WINTER, M. (2004). GEOGRAPHIES OF FOOD: AGRO-FOOD GEOGRAPHIES - FARMING, FOOD AND POLITICS. PROGRESS IN HUMAN GEOGRAPHY, 28(5), 664-670. HTTP://DOI.ORG/10.1191/0309132504PH512PR

YA, R. A., SERIES, T., \& LP, S. (2007). EXPLORATORY DATA Mining AND DATA Cleaning. Software Review, 23(DECEMBER), 9-11. HTTP://DOI.ORG/10.1002/0471448354 